\section{P. Dijkhuizen}

Ms. P. Dijkhuizen, Research fellow : Department Old- and New Testament Studies,

University of the Free State,

Bloemfontein.

E-mail: admin@neotestamentica.

org.za

ORCID: https://orcid.

org/0000-0002-3410-7661

DOI: http://dx.doi.

org/10.18820/23099089/actat.

Sup32.6

ISSN: 1015-8758 (Print)

ISSN: 2309-9089 (Online)

Acta Theologica 2021

Supp 32:70-89

Date received:

16 December 2020

Date accepted:

30 June 2021

Date published:

10 December 2021

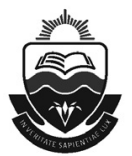

Published by the UFS http://journals.ufs.ac.za/index.php/at (c) Creative Commons With Attribution (CC-BY)

OPEN ACCESS
Conceptualising religion in the $21^{\text {st }}$ century: Examining the proposal of Mark C. Taylor in After God

\section{ABSTRACT}

This article summarises and evaluates Mark C. Taylor's theory of religion as presented in After God. Taylor redescribes religion as an emergent, complex, adaptive network - a term he adopts from the biosciences and physics. Such networks operate as non-totalising wholes. They are co-dependent and co-evolve. It follows that everything is related and there are no absolutes. Taylor points to the co-determination of religion and secularity as well as theology and theory in the West. Such networks are also self-organising and self-maintaining. As open systems, they thrive at the edge of chaos. Hence, Taylor rejects any closed, rigid system of neo-foundationalism as found in our postmodern, globalised world. For Taylor, there are no solid grounds; there is only creative emergence, from which reality is figured and disfigured in an oscillating interplay. The article closes by pointing out some inconsistencies in Taylor's own application of religion as complex adaptive system. Due to these inconsistencies, Taylor falls short of offering a constructive role for contemporary religious traditions and communities.

\section{PREAMBLE}

In a recent interview on the Hidden Forces platform, the host Demetri Kofinas (2017) asked Mark C. Taylor how he views the future. Taylor replied:

I am not overly optimistic. I mean I think that the world in which we find 
ourselves at this particular moment, not only in this country but across the world, represents ideas and ideologies that are the exact opposite of what is needed. What is most needed is to understand the interrelation and co-dependence of not only all peoples but of all things. ... Nietzsche says everything is entwined, enmeshed, interrelated. ... And until we learn our co-dependence and our interrelationship with other people ..., with the natural world, we are on a path of destruction, and there is no getting away from that destruction other than the cultivation of those systems and structures that support that interdependence.

Taylor has been called "the leading postmodern theorist of religion" (Robbins 2010:91) and "one of the leading and most creative figures in postmodern American religion" (Stiles 2002:157). His monograph After God (2007) is his most important work, as it forms "a synthesis of a lifetime of weaving together theological and cultural analysis" (Robbins 2010:92). This article examines the main tenets of Taylor's system of thought, as set out in After God. For Taylor (2007:xvii), a U-turn can be made on the path of destruction that he fears for humankind, only if the core concepts of relationalism as well as creative co-dependence and co-evolvement are acknowledged and promoted. Everything is related in the infinite web of life (Taylor 2007:355). To be is to be related, or in current terms, to be is to be connected (Taylor 2007:40, 229, 313). Notions of God, self, and world or their functional equivalents are interrelated and mutually condition and cultivate each other (Taylor 2007:22-24).

Taylor (2007:345) explains the title, After God, as follows:

But how is after to be understood? On the one hand, to come after is to be subsequent to what previously has been, and on the other hand, to be after is to be in pursuit of what lies ahead.

For Taylor (2007:345), "what previously has been" are the traditional Western ontotheological categories of God as the infinite ground of being, the underlying One, or God as the transcendent Other (Taylor 2007:377). What he is "in pursuit of" is a religion of life:

After God, the divine is not elsewhere but is the emergent creativity that figures, disfigures, and refigures the infinite fabric of life (Taylor 2007:xvii-xviii).

Taylor $(2007: 345,377)$ opines that the gods are always finite; the divine is incarnate in the eternal restlessness of becoming, which makes life in this world infinitely valuable. The lines are porous in After God. Taylor clearly expounds his own religion as much as a theory of religion. 
After God furthermore seeks to show why religion continues to play such an important role in the modern and postmodern world (Taylor 2007:42) and how it can so easily degenerate into a form of "religiosity" that simplifies reality and absolutises norms (Taylor 2007:42). To counteract such a process, Taylor (2007:42) aims to provide not only a more adequate religious vision, but also a non-absolutist ethical framework for negotiating the complexities and contradictions of life at the beginning of the $21^{\text {st }}$ century. There are no absolutes when everything is related. Life is a network of networks, co-dependent and co-evolving, and no one runs the show; there is no centre; there is only the constant process of becoming (Taylor 2007:355-356).

The task of the remainder of this article is to assess whether Taylor's arguments are robust enough to revitalise religious traditions and communities and offer solutions for urgent questions and dilemmas that the world faces at present.

\section{RELIGION AND SECULARITY AS CO-DEPENDENTS}

\subsection{Neo-foundationalism}

In After God, Taylor $(2007: 4,258)$ makes a strong case against all forms of fundamentalism, whether religious or scientific. He contends that neither those who defend nor those who attack religion nowadays have an adequate understanding thereof. Hence, they represent alternative versions of religiosity. Scriptural fundamentalism (whether Christian or Islam) is an example of such an inadequate version of religion. As it reifies and absolutises beliefs and practices, in order to arrive at certainty and enjoy security, it inevitably devolves into religiosity and causes the very disruption it was designed to avoid. Scientific reductive analysis, which intends to exhaustively explain the phenomenon of religion, is another example of destructive absolutism that builds on the false premise of a solid reality. Thus, religionists and secularists perceive themselves as irreconcilable opposites, while, in fact, they are mirror images of each other, each informing the other, demonstrating that there is co-dependence and co-evolvement of religious and secular beliefs and practices (Taylor 2007:132). Taylor (2007:222-223) illustrates this interrelatedness by juxtaposing "death-of-god" theology and the abolition of the gold standard in the economic sphere, resulting in a play of floating signs in both the networks of religion and economics - networks where the signifiers are no longer backed by the real referent or the signified, but are merely at play 
with each other. However, religious and scientific fundamentalists do not perceive the interconnectedness and co-emergence of these networks and networks of networks. They divide the world into exclusive opposites and adhere to the dualistic logic of either/or. For them, life without absolutes is a life without meaning and purpose (Taylor 2007:132, 279). Black and white thinking satisfies their longing for simplicity, authenticity, certainty, and security, which, alas, comes at the price of vitality (Taylor 2007:70). Taylor views religious and scientific fundamentalism as exponents of "neo-foundationalism", a symptom of and response to the process of globalisation and the emergence of information and network culture. As such, neo-foundationalism is a distinctly postmodern phenomenon (Taylor 2007:3, 258). To Taylor (2007:xvii-xviii), there is a fault line nowadays: it is not religion versus secularity, or theology versus theory; it is (neo)-foundationalism and absolutism versus creative emergence and relationalism.

\subsection{Religion and secularity in the West}

After God seeks to demonstrate the co-evolvement and co-dependence of religion and secularity in the West. This immediately confronts one with the limitation of this book. After God relies heavily on Christian and especially Protestant, even post-Protestant, models of religion. For this reason, Roberts (2009:101) concludes that $A f t e r$ God does not propose an adequate general theory of religion. Such a conclusion is premature, however. Taylor is very much concerned with developing an adequate theory of religion. He does so by using resources from the field of complexity studies such as biological systems and information networks. He also claims that he develops this theory out of the same Western philosophical and theological tradition that has informed modern and postmodern theoretical frameworks such as structuralism and poststructuralism. In other words, Taylor admits the theological and philosophical dimensions of his theory just as much as he recognises it in others. This provides his theory with the validity it needs to criticise the role of religion in contemporary society and to fashion an alternative religious vision (Taylor 2007:32, 298-299).

What is secularity? The simplest definition is that it is the state of being separate from religion. In After God, Taylor (2007:200) explores Western secularity, which he interprets as the disappearance of God or, rather, the disappearance of a particular notion of God. He notices that, throughout the history of religion in the West, God has repeatedly disappeared by becoming either so transcendent that he is irrelevant and nothing is no longer sacred (dualism), or so immanent that there is no longer a difference 
between the sacred and the secular (monism) (Taylor 2007:133). ${ }^{1}$ In view of this oscillating process, Taylor $(2007: 3,132)$ calls secularity in the West a religious phenomenon, inherent in religion; it is not imposed from the outside. Therefore, secularity cannot be viewed as the force that will irreversibly undo religion, as is often feared or assumed. The German philosopher Hegel, by creatively reinterpreting the doctrines of the Trinity and Incarnation, arrived at the conclusion that secularity does not entail the negation of religion. On the contrary, secularity is the fulfilment of religion. When God becomes incarnate in self and world, the secular and the sacred are reconciled. In this movement, transcendence negates itself not in absolute immanence as mentioned earlier, but in an immanence that always remains incomplete (Taylor 2007:154), in order to make infinite, emergent creativity possible (2007:164; see further §3.3 and §4).

Whether in lofty philosophical vision as with Hegel or in concrete daily life, it is not difficult to note a constant interplay between religion and secularity in our contemporary world. Both foundational religionists and foundational secularists overlook this important fact when they put the two in simplistic opposition. The sacred and the secular are not opposites. They are co-dependent and co-emergent. Religion, as it has developed in the West, has always harboured secularity, and secularity covertly continues a religious agenda (Taylor 2007:132). Taylor $(2007: 239,71)$ illustrates the latter by pointing to the divine status that is ascribed to the market in the contemporary market-state:

Far from secular, the market-state rests upon a foundational faith in the omniscience, omnipotence, and increasing omnipresence of the market. At the turn of the millennium, God is not dead; rather the market has become God in more than a trivial sense: human beings freely err but the market is never wrong. Just as Calvin's providential God weaves good out of evil, so the providential market redeems losses by creating ever-greater profits. ${ }^{2}$

Thus, religion can be most influential where it is least obvious. The gods or their functional equivalents can choose to go underground, from where they continue to "haunt" society, self, ${ }^{3}$ and culture (Taylor 2007:132).

1 In deism and neo-orthodoxy, God is transcendent; in Hegelian idealism and Protestant liberalism, God is immanent; see Taylor (2007:xvi, 200).

2 See also Taylor (2007:224): "The most influential interpretation of markets was originally developed during the eighteenth-century Scottish Enlightenment by theorists whose interpretation of the world was decisively shaped by their Calvinist heritage. In the Wealth of Nations (1776), Adam Smith translates the notion of divine providence into the invisible hand of the market."

3 The market-state needs the autonomous subject that emerged with the privatisation of religion during the Reformation period (Taylor 2007:224, 239-240; see also §2.3). 
On the other hand, secularity can be most influential where it is least obvious. For all their good intentions, spiritual entrepreneurs such as Joel Osteen (Taylor 2007:294) and Rick Warren (Taylor 2007:290) have commoditised religion in the open market of spiritual supply and demand, and the assuaging words of the gospel of prosperity have become indistinguishable from the secular remedy of "I'm OK - you're OK" (Taylor 2007:291) or "Go shopping!" (Taylor 2007:297).

\subsection{The theological genealogy of theory}

The theological genealogies of the critical theories of modernism and postmodernism also testify to the co-dependence and co-emergence of religion and secularity. As secularising movements, modernity and postmodernity are inseparably bound up with Protestantism (Taylor 2007:xiv). It follows that modernity and postmodernity are theological inventions and they must be recognised as such (Taylor 2007:xiv, 43). Martin Luther, leader of the Protestant revolution, invented the modern subject. Luther privatised and decentralised religion, by declaring the relation to God through faith individual and private or subjective. His notion of human subjectivity would eventually lead to the self-legislating autonomous subject of modernity. Autonomous subjectivity is the prerequisite for secularity. Luther also stressed the duty of Christians in public life. His notion of calling or earthly vocation (Beruf) again opened the door to modern secularity (Taylor 2007:64-65, 156). The theological revolution of Protestantism was accompanied by a social, political and economic revolution that continues to transform the world nowadays (Taylor 2007:6970, 78-79): the emergence of the nation-state (as opposed to the medieval feudal state); the information and communications revolution, due to the invention of print and the spread of literacy (but note that print has both individualising and standardising effects), and burgeoning capitalism. ${ }^{4}$

Taylor (2007:43) concludes that the modern world and its distinctive institutions - democracy, the nation-state, and the free market - are inseparable from Protestantism and its history. Modernisation and secularisation have unmistaken Protestant roots (Taylor 2007:43):

There is no doubt that modernity as it has emerged in the West and spread throughout the world would not be what it is without the Reformation.

This is not to say that the Reformation must be isolated from its wider context as if somehow impervious or superior to it. Taylor (2007:28; see

4 Calvin, not Luther, viewed capitalism as part of God's providential plan and accepted the practice of usury. 
also §3) views nature, society, culture (including religion) and technology as emergent complex adaptive networks that interrelate and co-evolve. As complex systems, these networks experience punctuated equilibrium. Development is punctuated, not smooth and continuous, and changes are episodic and unpredictable. Change comes about when the system has reached a condition of self-organised criticality - the tipping point. When such a point is reached, the effects of individual events become unpredictable and can be disproportionate to their causes (Taylor 2007:27). Luther's personal crisis was such an event. It was amplified as it tipped the balance, upsetting the equilibrium of pre-modernity and ushering in the Reformation and the modern age.

Luther and the other Reformers cast their shadow on both modernity and postmodernity. Taylor (2007:57) points to the pivotal pre-Reformation figure of William of Ockham who argued that God's omnipotent will is prior to and determinative of God's reason. Ockham's voluntarism introduced play into theology - divine play (Roberts 2009:100). Thomas Aquinas represented the alternative model, in which God's reason governs God's will. Aquinas' God is reasonable and never arbitrary, and the world is rational and orderly (Taylor 2007:52). For Taylor, the theistic models of Aquinas and Ockham reflect the two interrelated moments of religion: the one that structures and stabilises and the other that destructures and destabilises. Taylor calls Aquinas' theology a "theology of the Word", of which structuralism in all its manifestations is a latter-day version; Ockham's theology is a "theology of the Deed". As Ockham privileged divine will over divine reason and faith over knowledge, he anticipated poststructuralism with its emphasis on the instability of all foundational structures and the incompletion of all purportedly comprehensive systems (Taylor 2007:299-300).

Hence, theology and theory are closely related. Depending on where theology and theory are positioned within the trajectories of Word and Deed, they are either foundational or non-foundational. An adequate theory of religion, however, avoids either one of these poles. It captures both Word and Deed and recognises their co-dependence and co-evolvement. An adequate theory of religion acknowledges that religion both stabilises and destabilises (Taylor 2007:299-300). It is time to study Taylor's definition of religion. 


\section{DEFINING RELIGION}

\subsection{Redescription}

Theorists of religion redescribe. Their scholarly activity involves translating first-order expression, "insider" truths, both performative and reflective, into second-order theoretical abstraction or "outsider", epistemic truths. According to Smith (2004:208), there is, however, an even stronger mode of redescription, namely, when the second-order language appropriate to one domain may translate the second-order language appropriate to another domain. Taylor is involved in such an exercise in After God. He appropriates for his theory of religion the concept of "emergent, complex, adaptive network" from complexity studies such as studies on biological systems. In elaborating this concept, Taylor relies heavily on the apparatus provided by the theoretical biologist Stuart Kaufmann. Kaufmann (1995:8) postulates that spontaneous and emergent order underlies the origin of life. The idea of emergent stands for the whole is greater than the sum of its parts (Kaufmann 1995:24). Life is located, not in the property of any single molecule, but in the collective property of systems of interacting molecules (Kaufmann 1995:24). Life emerged whole and has always remained whole. Life is self-organising and self-maintaining. In fact, the self-organisation and self-maintenance of life are the preconditions for its evolvability. It is also life's fate to evolve to a natural state between order and chaos. Kaufmann (1995:26) explains:

[L]ife exists at the edge of chaos. Borrowing a metaphor from physics, life may exist near a kind of phase transition. Water exists in three phases: solid ice, liquid water, and gaseous steam. It now begins to appear that similar ideas might apply to complex adapting systems. For example, we will see that the genomic networks that control development from zygote to adult can exist in three major regimes: a frozen ordered regime, a gaseous chaotic regime, and a kind of liquid regime located in the region between order and chaos. It is a lovely hypothesis, with considerable supporting data, that genomic systems lie in the ordered regime near the phase transition to chaos. Were such systems too deeply into the frozen ordered regime, they would be too rigid to coordinate the complex sequences of genetic activities necessary for development. Were they too far into the gaseous chaotic regime, they would not be orderly enough. Networks in the regime near the edge of chaos this compromise between order and surprise - appear best able to coordinate complex activities and best able to evolve as well.

Evolvement, mutation, and adaptation happen at the location near the transition to chaos. It is as though this position affords the best mixture 
of stability and flexibility (Kaufmann 1995:91). And this being poised at the edge of chaos may be the fate, not simply of life as a whole, but of each and every emergent complex adaptive system or network, from single cell to economies, to political systems, and to religion (Kaufmann 1995:304). ${ }^{5}$ We inhabit a poised world, balanced on the edge of chaos, but not actually chaotic (Kaufmann 1995:90, italics added).

\subsection{Taylor's definition of religion}

Assuming with Kaufmann that all institutions, including religion, evolve as expressions of these deep natural principles, Taylor appropriates the conceptual language from the domains of the biosciences and physics by analogically mapping it onto the domain of religion, in order to formulate a second-order definition of the category of religion. Taylor (2007:12) proposes this definition:

Religion is an emergent, complex, adaptive network of symbols, myths, and rituals that, on the one hand, figure schemata ${ }^{6}$ of feeling, thinking, and acting in ways that lend life meaning and purpose and, on the other, disrupt, dislocate, and disfigure every stabilizing structure.

Taylor imagines religion as an open, relational, and non-totalising structure that acts as a whole. By formulating religion as an emergent, complex, adaptive system or network among a multiplicity of other networks, Taylor implies that religion or, more concretely, a religious tradition, is itself a whole made up of parts, and that such a religious tradition is intertwined and interconnected with all other wholes or networks in its relational web: natural, cultural, social, and technological networks, including networks of other religious traditions. These networks are co-dependent and codetermine each other, ${ }^{7}$ but one cannot be reduced to the other.

This is what Taylor (2007:310) has to say about complex adaptive systems that act as wholes:

Through the multiple nonlinear actions of related agents, complex adaptive networks act as a whole in a way that promotes unity

5 Taylor (2009:117) agrees when he writes that such systems are "isomorphic across media" and can also be applied to cultural and symbolic networks (for example, religion).

6 "Schemata" are regulating patterns within a system that are, however, able to modify themselves in relation to changing circumstances; see Taylor (2007:13-17). A high level of "schematization" is reached when symbols and myths integrate sense experience, information, and knowledge into patterns that provide meaning and purpose (Taylor 2007:19).

7 In this instance, Taylor (2009:113) introduces the word "fractal": these networks or systems display the same structure at all levels and in all operational phases. 
without necessarily becoming repressive. In these relational webs, co-dependent individuals emerge and co-evolve through processes of punctuated equilibrium in which disruptive change issues in creative transformation.

Change is necessary. Mutations are creative disfigurings that allow new figures to emerge.

The new emerges far from equilibrium at the edge of chaos in a surprising moment of creative disruption that can be endlessly productive (Taylor 2007:xvii).

Figuring and disfiguring are co-dependent. The moments of figuring and disfiguring represent the oscillating interplay between stability and instability or order and chaos in religion. ${ }^{8}$ Any interpretation of religion that associates religion with only one of these poles to the exclusion of the other is inadequate (Taylor 2009:110). The dynamics of complex adaptive systems are the dynamics of creative emergence through which patterns, forms, and schemata are figured, disfigured, and refigured. Taylor (2007:114) describes figuring as an emergent activity of the imagination; it is, therefore, productive and creative. The term "figure" can refer to form (object) and to forming or comprehending (activity). Refiguring is recombinant, that is, reproductive and re-creative. It occurs when schemata are adjusted (Taylor 2007:20). Disfiguring is de-forming, acknowledging that something cannot be represented or comprehended. Far from simply destructive, disfiguring keeps figures open and is the condition of the possibility of creative emergence. Figures always include something that can neither be represented nor comprehended; hence, they are disfigured as if from within (Taylor 2007:20, 119, 307).

\subsection{The imagination, (dis)figuring, and creative emergence}

For Taylor, relying heavily on Kantian philosophy, the imagination is crucial in the moments of figuring, refiguring (constructive), and disfiguring (deconstructive). He has an expanded and daring understanding of the imagination as a fundamental ontological concept: the imagination is the basis of all reality, both subjective and objective (Taylor 2007:116, 124).

8 Or construction (structuralism) and deconstruction (poststructuralism). Structuralism emphasises that forms and patterns are needed for creating the order, without which life would be impossible, but it fails to explain how these structures emerge and change over time. Poststructuralism, on the other hand, calls into question every system constructed to provide security and stability. It claims that systems inevitably totalise. It cannot conceive of non-totalising structures that act as wholes (see Taylor 2007:12; 308-310). 
Through figuring, the world (natural forms, types, concepts, ideas, and so on) is quite literally created, and this occurs spontaneously, "grounded" in freedom (Taylor 2007:116, 122). But how are figures figured? The answer is: "Just as God creates freely ex nihilo, so the productive imagination creates freely out of nothing" (Taylor 2007:117). This no-thing is the abyss, the Abgrund, the groundless ground of the imagination (Taylor 2007:116-117). Thus, the origin of figuring is unfathomable, but so is the process: no figure can befully presented; there is always something irreducibly unrepresentable in "presencing" (Taylor 2007:119). This marks the figure's openness and its infinite excess, but also its incompleteness and incomprehension. The same applies to self-consciousness and self-representation. The self-assubject and the self-as-object are co-dependent; neither is the origin of the other. In fact, the origin is groundless, is "an-archy" (Taylor 2007:116), and this yields an incomprehensible, unrepresentable Other inside the heart of subjectivity. Deus absconditus has become subjectus absconditus, but "[i]nfinite obscurity is what makes endless creativity possible" (Taylor 2007:120). As theology becomes anthropology, God and the imagination become one (Taylor 2007:117, 122, 311). Sandbeck (2011:26) concludes that, in this instance, "the imagination is the God that comes after the death of the transcendent God of metaphysics".

The co-dependent of figuring is disfiguring. The imagination is involved in both:

The imagination is the activity through which the figures that pattern the data of experience emerge, are modified, and dissolve (Taylor 2007:307).

Figures come and go; they must come and go. Seemingly secure and stable figures, schemata and systems cannot adapt to changing circumstances. Excessive order must drift toward chaos. And this disruptive, destructive, restless, non-teleological, and endless process is the condition of the creative emergence of new patterns of order (Taylor 2007:347). It is only when complex systems remain non-fixed that they are open to endless transformation (Taylor 2007:311). In Taylor's webby world, nothing is clear, distinct, fixed, or stable (Taylor 2009:117). In fact, Taylor (2008:n.p.) admits that his interest lies with the activity of disfiguring, the moment of deconstruction. What he fears most is the drift from religion to religiosity - the undue predilection for the stabilising moment. Rather than the purportedly unshakable schemata of neo-foundationalism, Taylor (2007:347) puts forward the emergent schemata of complex dynamic networks that are like "subtly shifting pockets of stability in the midst of fluxes and flows". With Taylor (2007:185), "the edge of chaos" has 
become the "unfigurable edge", along which life is lived (Taylor 2007:347). Nikkel (2013:467) rightly concludes that the disfiguring element claims metaphysical ultimacy in Taylor's system.

\begin{abstract}
God is not the ground of being that forms the foundation of all beings but the figure constructed to hide the originary abyss from which everything emerges and to which all returns. While this abyss is no thing, it is not nothing ${ }^{9}$ - neither being nor nonbeing, it is the anticipatory wake of the unfigurable that disfigures every figure as if from within. Far from simply destructive, disfiguring is the condition of the possibility of creative emergence (Taylor 2007:345).
\end{abstract}

Prominence, indeed, appears to be given to the activity of disfiguring, which is associated with the destructuring or destabilising pole in religion. In this instance, there is an asymmetry that may undermine Taylor's own definition of what an adequate religion entails, namely the endless play of both figuring stable and meaningful patterns and of disfiguring these (see further §4.1). Even though Taylor (2007:345) claims that disfiguring is "far from simply destructive", Taylor does not really work out how disfiguring becomes the vehicle of transformation, with new forms appearing out of the ashes of the old ones. One is literally left to one's own imagination.

When Taylor moves to the activity of figuring the real, an activity in which each religious tradition is involved, he again zooms in on the unstable, the indeterminate and the restless, at the expense of the secure, the evident, and the fixed. Taylor opts for a complex model whose logic is "neither/ nor": reality is neither here and now (monism) nor elsewhere and beyond (dualism). Taylor (2007:40-41) calls reality "virtual", which he describes as "the elusive real in and through which everything that exists comes into being and passes away". The virtual is not simply the possible, or worse, the unreal, but it is the fluid matrix in which all possibility and actuality arise and pass away (Taylor 2007:311). Whereas in monism the divine is the underlying One, which dissolves differences, and in dualism the transcendent Other, which divides more than unites, in Taylor's (2007:377) complex model, the divine is incarnate in the eternal restlessness of becoming. And infinite restlessness issues in emergent creativity (Taylor 2007:41).

"Emergent creativity" (or "creative emergence"; the two are used interchangeably) is a key concept in After God. Without this creativity, there is no life:

9 While negation with negation is undeniably negative, it is, more importantly and at the same time, radically affirmative, insofar as it is the condition of creative emergence of everything that exists (see Taylor 2007:117; Stiles 2002:149). 
After God, the divine is not elsewhere but is the emergent creativity that figures, disfigures, and refigures the infinite fabric of life (Taylor 2007:xvii-xviii).

Taylor (2009:117) allows the creator God to die, in order to have "him" reborn as emergent creativity deemed divine. For Taylor (2007:163), this is the unexpected culmination of the classic doctrine of the Incarnation. God dies and is reborn as the infinite creative process that endlessly emerges in space and time. This virtual reality resembles an "immanent transcendence" (Taylor 2007:41, 311). In such a reality, what was once named "being" turns out to be irreducibly temporal: the event of emergence is never present, but always already past; the origin, therefore, is forever missing (Taylor 2007:309). Hence, God, the being-itself, the once-believed substance of all things, does not exist (Taylor 2007:311-312). After God, "the endless restlessness of the Infinite is the eternal pulse of life" (Taylor 2007:312, 345). Life is its own end or purpose. In other words, life is an activity that is "autotelic": the end of life is life itself, just as the work of high art is created for its own sake. It is not about the end product; the telos of the living organism and the work of art is the creative activity as such (Taylor 2009:115). Life is also "autopoietic": life creates itself in a process that is self-renewing and infinite (Taylor 2007:317). The self-organisation and self-maintenance of life is the precondition of its evolvability. All emergent, complex, adaptive systems share this operational logic with life. With self-organising systems, order is not imposed from without, but emerges from within. There is no need for a designer who remains external of the creation; there is no need for a transcendent "clockmaker" (Taylor 2009:115). For Taylor (2007:185), emergence - creative emergence - is central:

At the edge of chaos lurks not only danger but also the prospect of creative emergence, which harbors the only hope that remains.

\subsection{Relationalism}

As already touched on in $\$ 1$, instead of absolutism, Taylor proposes relationalism. He applies this first, to knowledge, which he describes as "webby" (Taylor 2009:117), since in complex adaptive systems there is co-emergence and co-evolvement of the webs or networks of nature, culture, society, and technology (Taylor 2009:114); hence, knowledge is always relational. Secondly, with regard to morality, Taylor (2007:356-358) proposes an ethics without absolutes that is adequate for contemporary network culture and that promotes global life. Absolutism, whilst striving for a closed, uncompromising system and a dualistic logic of either/or, is self-defeating, because it negates the other without whom one cannot be 
what one is (Taylor 2007:349). Ultimately, knowledge and morality, theory and practice, thinking and acting are co-dependent (Taylor 2007:355; 2009:118).

Taylor claims that the Western religious tradition has rich resources available for denoting the structure of reality as relational. It was noted earlier how the Christian doctrine of the Incarnation, interpreted in Hegelian terms, means that secularity is the fulfilment of religion: God is real only by becoming incarnate in self and world, and thus, whatever exists is an incarnation of divine reality (Taylor 2007:154, 163). But the doctrine of the Incarnation requires the doctrine of the Trinity: "The reconciliation believed to be in Christ has no meaning if God is not known as triune" (Taylor 2007:159, quoting Hegel). Taylor (2007:158-159) further explains this triadic structure:

There is no Father without the Son and no Son without the Father; Spirit fashions a unity that constitutes and sustains differences.

This unity is organic; this Father-Son identity is differential, and their self-engendering relational activity is Spirit. The classic doctrine of the Trinity yields inclusive and complex notions of unity and identity. In fact, if God is triune, constitutive relationalism is the structure of all reality and as such is divine (Taylor 2007:159). The triadic structure of the Trinity is isomorphic with the triadic structure of self-consciousness: ${ }^{10}$ self-assubject (Father), self-as-object (Son), and the interrelation of the two (Spirit). But lest we mistake Taylor's drawing on trinitarian structure, in this instance, as a return to premodern orthodoxy and the creeds of Nicaea and Chalcedon, he warns:

The complexity and vitality of this relationship cannot be represented in the simple and static language of substance but must be grasped in terms of dynamic subjectivity (Taylor 2007:161, italics added).

As subjects, the triune God and the self are of differential, not static, identity. Subjectivity is the vital interplay in and through which differences arise and pass away (Taylor 2007:162). Taylor calls subjectivity "nodular": every subject is a node in a complex web of relations that constitute its identity as differential (Taylor 2007:40, 382; see also Rickert et al. 2004:809). This implies openness, incompleteness, excess (see §3.3) - qualities that make infinite creativity possible. To Taylor $(2007: 142,159)$, the Trinity reveals God to be a self-engendering and self-organising creative process.

10 See Taylor (2007:160-161). Taylor follows Hegel who applies the trinitarian structure to selfconsciousness, the concept, reason, and the Spirit; see Lakeland (1988:60). 
This puts "God" right inside the endless process of becoming, of creative emergence - and not outside of it.

\section{EVALUATION}

After God offers an alternative to (neo-)foundational ways of practising and studying religion. It is refreshing to observe how Taylor dissolves, from within, the old binaries of religion versus secularity (or the extremes: religiosity versus secularism), and theology versus theory. He "disfigures" a sacred cow in the academy when he asks: "What is the difference between the study and the practice of religion?" (Taylor 2009:117). Indeed, the lines between these two are at play in After God, as Taylor (2007:377) presents both a theory of religion and his own religion of the divine as "endless becoming" and "infinite life". In this last section, I evaluate two aspects of Taylor's religious vision that appear to be incompatible or out of balance with his own theoretical framework and that make it difficult for existing religious systems to assimilate Taylor's thought.

\subsection{The prioritisation of the destabilising pole}

In contrast to neo-fundamentalist forms of belief, which provide certainty, security, purpose and meaning, the religion I imagine calls everything into question and leaves us open to the creative uncertainty of the future. That future does not, I think, involve anything traditional believers imagine as salvation. There is no transcendent beyond; we are destined to dwell in an arising and passing away that does not arise and pass away. ${ }^{11}$

Taylor's "confession" puts him in an uncomfortable relationship with existing ontotheological religious traditions. He emphasises, in the interview in the opening section of this article $(\S 1)$, that there is a need for the cultivation of "those systems and structures" that support relationalism and interdependence. It can be argued that an existing religious system such as Christianity has figured and continues to (re)figure - through its symbols, myths, and rituals - schemata of feeling, thinking, and acting that concern the value and potential of life and humankind's interrelationship with all things, and in this way provide life with meaning and purpose (see Nikkel 2013:476-477). Does Taylor (2007:26) express or allude to a positive, constructive role for an existing religious system such as Christianity in this moment of "self-organised criticality", in which the world finds itself at present? This question is difficult to answer, especially as Taylor expresses a strong predilection for the activity of disfiguring, not figuring, as was discussed in §3.3. Taylor (2007:xviii, 41, 119-120, 345,

11 Taylor in Rickert et al. (2004:814, italics added). 
$347,357 ; 2009: 117)$ embraces, even delights in, uncertainty, disruption, disorder, dissatisfaction, volatility, absence, incomprehension, and the unrepresentable. Hence, Taylor would not consider any conservative or foundational version of Christianity adequate, as has amply been shown by now. But is Taylor not at risk for straying to the other extreme: destabilising, destructuring and deconstruction all the way down?

The aim of Taylor's project in After God can be summed up, in Taylor's own words (see Rickert et al. 2004:807), as an attempt to bring together philosophical ideas ${ }^{12}$ with theories of emergent, self-organising systems that can be found in nature, society, and culture. Does Taylor succeed? At the heart of his methodology is the redescription of religion as an emergent, complex, adaptive network. Such networks need the maintenance of a minimal basic structure so as not to go extinct. ${ }^{13}$ Moreover, change occurs optimally in the region between order and chaos (Freeman 2011:4; see also §3.1):

Commonly named the "edge-of-chaos", it is precisely here in this critical state delicately poised between too much rigidity and too much fluidity that evolving systems in open energy exchange have the significant tendency to evolve towards new, more complex adaptive structures.

Complex adaptive systems thus function best when they combine order and chaos in an appropriate measure (Chan 2001:6). Lastly, the phenomenon of "punctuated equilibrium" means that periods of overall disequilibrium are the exception rather than the rule. Taylor (2007:27) himself, writing in the context of the evolution of complex adaptive systems, explains: "Since development is punctuated rather than continuous, change is episodic and unpredictable."

Consequently, in order to stay congruent with his own theoretical model, Taylor needs to balance figuring and disfiguring. Resorting to Taylor's own definition of religion once more (see §3.2), how does Taylor figure schemata of feeling, thinking, and acting in ways that lend life meaning and purpose? This is Taylor's (2007:41) best and most succinct answer: "[T]he aim of life is to embrace the infinitely creative process whose purpose is nothing other than itself."

12 Foremost: Kant, Hegel, Kierkegaard, Nietzsche, Heidegger, and Derrida. As shown in §3.3, Taylor tends to focus on the destructuralist side of these philosophies, always drifting towards the cliff edge of the abyss, the Abgrund, the no-thing, at the limits of living and knowing; see, for instance, his treatment of Kant (Taylor 2007:116-118) and Hegel (Taylor 2007:164); see also Nikkel (2013:471, 473).

13 Nikkel (2013:468-471) argues this point from the networks of physics and biology. 
Just like a work of art is all about the creative process and creation for its own sake, so life and religion should be: "After God - art; after art - life. Three-in-one - One-in-three" (Taylor 2007:345). This brings me to another aspect of Taylor's religious vision, namely the role and function of art that may again cause a clash with his theoretical model and put everything "up in the air" so to speak (to use a pun on Kaufmann's terminology of the "gaseous chaotic regime"; see §3.1).

\subsection{Art as means and end}

For Taylor (2007:31), the networks of philosophy, religion and art are located within the larger network of culture, which, of course, overlaps with other overarching networks, namely nature, society, and technology. Taylor (2007:32) stresses that all of these networks are co-dependent and co-emergent; hence, every form of reductive analysis is wrong. So, whilst co-evolving with other networks, religion cannot be reduced to, for instance, art or philosophy, and vice versa. All of this sounds good on paper. However, just as in $\S 4.1$, I see a tension between the implications of Taylor's theoretical model of religion as a complex adaptive network among other networks on the one hand, and his philosophical ideas, on the other. The latter may well cause religion - or, more specifically, Taylor's own religious vision - to be usurped by one or both of the other cultural networks, namely art and philosophy.

According to Taylor (2008:n.p.), one can only figure the unfigurable (and this is what philosophy and religion attempt) when one's style is "deliberately artful". ${ }^{14}$ As noted in $§ 3.3$, in Taylor's view, the imagination figures forms freely and spontaneously out of unfathomable depths. These qualities are traditionally associated with the poetic imagination. The vast majority of religious traditions will agree with Taylor that the imagination has a role to play in cultivating the expression of the "unfigurable" or whatever term such traditions prefer as functional equivalents. It is true, religious traditions may want to stress refiguring as much as figuring, as their community of adherents are, to some extent, traditioned, and refiguring stands for recombinant, re-creative figuring.

Yet, for Taylor (2007:122), the imagination is much more than a faculty of the creative subject: it also creates the objective world. Taylor

14 Taylor elaborates on this in his later work Rewiring the real (2013), in which he contrasts two philosophical styles or, rather, two ways of thinking, writing, and even living: "one acknowledges and cultivates the poetic, artistic, and literary characteristics of creative work, and the other denies and represses them" (Taylor 2013:281). In Taylor's (2013:10, 281) view, modern analytical (in other words, "foundational") philosophy is an exponent of the style that represses artistic and aesthetic facets, whereas postmodern continental (in other words, "non-foundational") philosophy expresses these. 
(2007:343), quoting the Romanticist Schlegel, thus states "no poetry, no reality". The flipside is that one must understand this world as a work of art. "Poetry" derives from the Greek poiesis, which refers to all productive and creative activity (Taylor 2007:124). It follows that the beautiful work of art is isomorphic with the living organism: both are simultaneously endless creative process and created product, autotelic and autopoietic (see §3.3). This, for Taylor (2007:343), sums up the integration of art and life: to understand life, it must be grasped as a work of art; at the same time, the work of art follows the living organism in structure and in operational logic.

Where does this leave religion and philosophy? For Hegel, art, religion and philosophy are three versions of one truth (Houlgate 2020:n.p.); hence, they are truly co-dependent. Taylor (2007:345), instead, quotes the famous words of Wallace Stevens: "After one has abandoned a belief in god, poetry is that essence which takes its place as life's redemption" (Stevens 1959:158). Taylor (2009:116) appears to join the list of Romanticists for whom art has displaced religion; for whom religion is a matter of aesthetic intuition rather than knowledge and morality. But, returning to Taylor's declaration at the closing of the previous section, "After God - art; after art - life ...", it appears that with Taylor, ultimately, art, religion, and philosophy are swallowed up in life, their intrinsic end goal being the infinite process of becoming, of creative emergence.

\section{CONCLUDING REMARKS}

Taylor does not always practise what he preaches. At the points where Taylor diverges from his own theoretical model, as shown earlier, his analysis in After God falls short of being a clear guide to contemporary religious traditions and communities. Still, the validity of his redescription of religion as a complex, adaptive network stands; so does his emphasis on both the interrelationship of all of reality's networks and the infinite value of life. Cupitt (2003:2) notes that "life has become our most popular totalising word". In the last chapter of After God, Taylor demonstrates the fragility of this life, by focusing on the current water crisis. After reading and re-reading After God, I have to admit that Taylor's arguments are often convoluted, his language often opaque, yet his overall message on what I would call the sacredness of life is as relevant and urgent as ever in 2020 a year that records the hottest temperatures on record (Borenstein 2020); a year of which the secretary-general of the United Nations said that it is the very moment of "self-organised criticality", the "tipping point", with regard to climate change and the self-maintenance of life on this planet (Sengupta 2018). In After God, relationalism and creative emergence fulfil the age-old doctrines of the Trinity and the Incarnation. This is how the sacred and 
the secular meet. One can only hope that Taylor's message will inspire many, so that the "path of destruction", about which he spoke in the 2017 interview (see §1), can be averted.

\section{BIBLIOGRAPHY}

Borenstein, S.

2020. It's close, but 2020 likely to end up hottest year on record. [Online.] Retrieved from: https://www.nbcmiami.com/news/local/its-close-but-2020likely-to-end-up-hottest-year-on-record/2343840/ [15 December 2020].

CHAN, S.

2001. Complex adaptive systems. Research seminar in engineering systems. [Online.] Retrieved from: http://web.mit.edu/esd.83/www/notebook/ Complex\%20Adaptive\%20Systems.pdf [25 November 2020].

CuPITT, D.

2003. Life, life. Santa Rosa, CA: Polebridge Press.

Freeman, C.

2011. Creative tension at the edge-of-chaos: Towards an evolutionary Christology. [Online.] Retrieved from: https://metanexus.net/creative-tensionedge-chaos-towards-evolutionary-christology/ [27 November 2020].

Houlgate, S.

2020. Hegel's Aesthetics. The Stanford Encyclopedia of Philosophy. Edward N. Zalta (ed.). [Online.] Retrieved from: https://plato.stanford.edu/archives/ spr2020/entries/hegel-aesthetics/ [29 November 2020].

Kaufmann, S.

1995. At home in the universe: The search for the laws of self-organization and complexity. New York, NY: Oxford University Press.

KoFINAS, D.

2017. Art, finance, technology, and the individual - A conversation with philosopher Mark C. Taylor. [Online.] Retrieved from: https://www. youtube. com/watch?v=CUnK5VosC1M, at 1:33:10 [26 November 2020].

LAKELAND, $P$.

1988. A new pietism: Hegel and recent Christology. Journal of Religion 68(1):5771. https://doi.org/10.1086/487715

NIKKEL, D.H.

2013. Rebalancing the poles in Mark C. Taylor's (a)theology. Theology Today 69(4):463-477. https://doi.org/10.1177/0040573612463032

Rickert, T., Blakesley, D. \& TAYLoR, M.C. 2004. An interview with Mark C. Taylor. Journal of Advanced Composition 24(4):805-819 (Special Issue: Complexity Theory). 
RobBins, J.W. 2010. Mark C. Taylor, After God (Review). The Journal of Religion 90(1):91-92.

RoberTs, T. 2009. All work and no play: Chaos, incongruity and différance in the study of religion. Journal of the American Academy of Religion 77(1):81-104. https://doi. org/10.1093/jaarel//fp012

SANDBECK, L. 2011. God as immanent transcendence in Mark C. Taylor and John D. Caputo. Studia Theologica 65:18-38. https://doi.org/10.1080/0039338X.2011.578362

Sengupta, S.

2018. U.N. Chief warns of a dangerous tipping point on climate change. New York Times 10 September. [Online.] Retrieved from: https://www. nytimes.com/2018/09/10/climate/united-nations-climate-change. html?em_pos=small\&emc=edit_clim_20180912\&nl=climatefwd\&nl_ art=2\&nlid=84723763c\%3Dedit_clim_20180912\&ref=headline\&te=1 $[29$ November 2020].

SMITH, J.Z.

2004. Bible and religion. In: J.Z. Smith (ed.), Relating religion: Essays in the study of religion (Chicago, IL: The University of Chicago Press), pp. 197-214.

Stevens, W. 1959. Opus posthumous. S.F. Morse (ed.). London: Faber \& Faber.

StiLES, K.M. 2002. Disfiguring harmony: Reconciliation, Mark C. Taylor, and postmodern theological aesthetics. Wesleyan Theological Journal 37(1):131-157.

TAYLOR, M.C. 2007. After God. Chicago, IL: University of Chicago Press.

2008. Q \& A with religion professor Mark C. Taylor. Columbia News, 3 January. [Online.] Retrieved from: https://cup.columbia.edu/author-interviews/taylorrewiring-real [25 November 2020].

2009. Refiguring religion. Journal of the American Academy of Religion 77(1):105-119. https://doi.org/10.1093/jaarel//fp011

2013. Rewiring the real: In conversation with William Gaddis, Richard Powers, Mark Danielewski, and Don DeLillo. New York, NY: Columbia University Press.

Keywords

Theory of religion

Mark C. Taylor

Secularity

Neo-foundationalism
Trefwoorde

Teorie van godsdiens

Mark C. Taylor

Sekulariteit

Neo-fondasionalisme 